\title{
Prinsip-Prinsip Keluarga Kristen Sebagai Pusat Pendidikan Menurut Ulangan 6:1-25
}

\author{
Paulus Kunto Baskoro \\ Sekolah Tinggi Teologi Injili Indonesia, Yogyakarta \\ paulusbaskoro1177@gmail.com
}

\begin{abstract}
Education in the family is a vital element for the strength of a family. The backgrounds of this writing are: First, there is the unconsciousness of some family of believers about the importance of the family as the center of teaching. Second, there are some couples or families of believers who are too busy with outside work rather than taking care of family life. Third, many Christian families today only focus on making ends meet. Fourth, many Christian families are currently experiencing problems regarding the impact of families with worldly life. This research uses descriptive method, namely studying the principles of the Christian family as a teaching center according to Deuteronomy 6: 1-25 which is a special revelation. Which finally has a big goal, First, for every family of believers to realize how important the family is as the center of teaching. Second, it is hoped that every family of believers can understand each other and encourage family after family. Third, the most essential thing is that every family of believers can become a figure or role model in the focus of the family being the center of teaching.
\end{abstract}

Keywords: Principles, Christian, Family, Teaching Center

\begin{abstract}
Abstrak
Pendidikan dalam keluarga menjadi elemen penting bagi kuatnya sebuah keluarga. Latar penulisan ini adalah: Pertama, adanya ketidaksadaran beberapa keluarga orang percaya tentang pentingnya keluarga sebagai pusat pengajaran. Kedua, ada beberapa pasangan atau keluarga orang percaya yang terlalu sibuk dengan pekerjaan di luar rumah daripada mengurus kehidupan keluarga. Ketiga, banyak keluarga Kristen saat ini hanya fokus mengejar untuk mencukupi kehidupan hidup saja. Keempat, banyak keluarga Kristen yang saat ini sedang mengalami masalah tentang terpengaruhnya keluarga dengan kehidupan duniawi. Penelitian dalam artikel ini menggunakan metode deskritif, yaitu mempelajari Prinsip-Prinsip Keluarga Kristen Sebagai Pusat Pengajaran Menurut Ulangan 6:1-25 yang merupakan pewahyuan khusus. Dengan memiliki sebuah tujuan besar, Pertama, supaya setiap keluarga orang percaya menyadari betapa pentingnya keluarga sebagai pusat pengajaran. Kedua, diharapkan setiap keluarga orang percaya dapat saling memahami dan mendorong keluarga demi keluarga. Ketiga, hal yang paling hakiki adalah setiap keluarga orang percaya dapat menjadi figur atau teladan dalam fokus keluarga menjadi pusat pengajaran.
\end{abstract}

Kata kunci: Prinsip, Kristen, Keluarga, Pusat Pendidikan 


\section{PENDAHULUAN}

Pengajaran dalam keluarga merupakan hal yang sangat penting, untuk mewujudkan keadaan atau suasana kehidupan keluarga yang harmonis dan bahagia. Sorotan tajam ini ditujukan kepada pendidikan bagi keluarga Kristen. Dilema keluarga ini lebih luas dikomentari oleh Scheunemann, yaitu, keluarga harus dibangun dengan serius sebab mempengaruhi masa depan gereja juga bangsa dan negara. ${ }^{1}$ Pendidikan dan pembinaan keluarga betul-betul penting. Disadari atau tidak, dampak dinamika kehidupan pendidikan dalam keluarga berpengaruh atas pertumbuhan rohani. Bahwa pendidikan dalam keluarga memegang poros utama membentuk keluarga dan kehidupan yang indah serta berkenan di hadapan Tuhan.

Hal senada ditegaskan lagi oleh Yusuf BS, yaitu, “Tidak cukup memperhatikan diri kita sendiri saja, sungguh tidak cukup." Namun harus memperhatikan keluarga juga, lebih-lebih anak-anak, kalau tidak maka pengaruh dan akibat-akibat yang busuk akan keluar dari keluarga yang dapat menghancurkan

\footnotetext{
${ }^{1}$ D. Scheuneman, Romatika Kehidupan Suami Istri (Malang: Gandum Mas, 1992), 8.

${ }^{2}$ Yusuf BS, Krisis Keluarga (Malang: STT Tabernakel, 1986), 8.

3 Anita Mauboy and Sjanette Eveline, "Pemahaman Pernikahan Kudus Suku Dawan
}

segala hidup, ibadah dan pelayanan. ${ }^{2}$ Suatu pernyataan umum yang sering muncul dalam nuansa pembicaraan tentang makna keluarga adalah "Keluarga itu pada dasarnya direncanakan oleh Allah" yang juga disertai suatu amanat kultural (reproduksi) dalam Kejadian 1:27-28. Dilanjutkan dengan disodorkan Allah kepada Adam yaitu Hawa yang berasal dari tulang rusuknya sendiri, untuk menjadi istrinya. Ditekankan dalam Kejadian 2:21-25 bahwa laki-laki akan meninggalkan orang tuanya dan menjadi satu dengan istrinya. Namun tidak cukup sampai di situ saja pemahaman Kristen tentang keluarga rencana dan berkat Allah dalam ungkapan "Beranak cuculah dan penuhilah, serta taklukkanlah bumi (Kej. 1:28), jika dihubungkan dengan pembentukan Allah terhadap keluarga pertama kali (Kej. 2:21-25), maka muncullah maksud mulia, yaitu: keluarga yang indah, harmonis dan memiliki tanggung jawab, serta hidup senantiasa berkenan di hadapan Tuhan. ${ }^{3}$

Keluarga merupakan sebuah lembaga terkecil yang di-design Tuhan dan merupakan lembaga pertama yang diciptakan Tuhan. ${ }^{4}$ Allah sangat serius

Ditinjau Dari Kejadian 1:27-28," Journal KERUSSO 4, no. 2 (2019): 23-32.

${ }^{4}$ AGUNG GUNAWAN, "Hamba Tuhan Dan Keluarga," SOLA GRATIA: Jurnal Teologi Biblika dan Praktika 3, no. 1 (2020). 
dengan keluarga. Sebab keluarga adalah implementasi kemuliaan Allah di dalam dunia. Terlebih lagi sebagai keluarga Kristen, harus sadar betul bahwa keluarga menjadi ujung sebuah kegerakan, kalau keluarga pulih, gereja akan mengalami pemulihan, kalau gereja dipulihkan, maka kota dan bangsa akan mengalami pemulihan yang dahsyat dan kualitas karakter hidup terus meningkat. ${ }^{5}$ Keluarga merupakan karya Allah yang luar biasa di dalam dunia ini. Hal ini terbukti dengan pemeliharaan Allah bagi manusia yang diungkapkan dalam Kejadian 1:27-28, 31. Makna yang timbul dalam Kejadian 1:27, 28, 31 itu menyatakan suatu ide bahwa keluarga adalah gagasan Allah sendiri, seperti yang ditegaskan oleh Roy Lessin. Keluarga merupakan gagasan Allah. Ia menentukannya. Ia mempersatukan lakilaki dan perempuan yang pertama dalam pernikahan. Hubungan mereka baik. Allah memberkatinya. Hubungan itu dimaksudkan untuk menimbulkan suasana kasih dan kepemimpinan untuk anak-anak yang merupakan buahnya. $^{6}$ Dengan demikian keluarga itu tidak pernah lepas dari karya Allah senantiasa. Allah mengontrol kehidupan keluarga, Allah yang bercampur tangan dalam kehidupan

${ }^{5}$ Mariani Harmadi and Agung Jatmiko, "Pembelajaran Efektif Pendidikan Agama Kristen Generasi Milenial," PASCA : Jurnal Teologi dan Pendidikan Agama Kristen 16, no. 1 (2020): 62- keluarga baik persoalan kecil maupun besar. Karya Allah itu meliputi segenap kehidupan keluarga, karena lembaga ini Allah sendiri yang membentuk sejak mulanya. Jadi keluarga di hadapan Allah merupakan suatu lembaga yang indah, dari dahulu (Kej. 1:27-28) sampai sekarang. Berkaitan dengan masalahmasalah yang timbul. Latar belakangnya, dilihat dari segi konteks keluarga sebagai pusat pendidikan. Supaya dalam pemecahan masalah, ada suatu pemahaman yang komprehensif dan menyatakan suatu prinsip, berdasarkan Ulangan 6:1-25.

Satu perkara yang harus dimengerti oleh berbagai lembaga keluarga masa kini adalah kehidupan itu terpengaruh oleh lembaga keluarga itu sendiri. Pemikiran ini sangat salah sekali, seperti komentar dari Roy Lessin, "Harus dimengerti bahwa bukan lembaga keluarga itu yang salah, tetapi cara hidup keluarga-keluarga masa kinilah yang menjadi masalah ${ }^{\text {"7 }}$ Kehancuran keluarga terjadi karena banyak pergumulan dalam keluarga yang tidak terselesaikan dengan baik.

Pendidikan keluarga memegang pilar yang penting untuk terciptanya

\footnotetext{
74.

${ }^{6}$ Roy Lessin, Disiplin Keluarga (Malang: Gandum Mas, 1987), 13.

${ }^{7}$ Lessin, Disiplin Keluarga.
} 
suasana kehidupan keluarga yang harmonis. ${ }^{8}$ Keharmonisan hubungan itu tercipta antara suami dengan istri atau sebaliknya orang tua dengan anak dan anak dengan orang tua. Oleh sebab itu, Allah menuntut adanya tanggung jawab dari setiap keluarga yang ada, dengan dihadirkannya pendidikan dalam keluarga yang bermutu. Dengan adanya pendidikan yang matang, terutama orang tua kepada anaknya, maka keluargakeluarga dalam Tuhan pasti menjadi keluarga yang handal dan senantiasa hidup berkenan di hadapan Tuhan. ${ }^{9}$

Dalam penelitian terhadap konsep keluarga dalam Kitab Suci, maka mula pertama penelusuran terhadap ide atau makna keluarga terdapat dalam kitabkitab tulisan Musa. Kitab Ulangan 6:1-25 yang akhirnya memenuhi standar pembahasan tentang keluarga sebagai pusat pendidikan, sebab Ulangan 6:1-25 menjadi acuan pendidikan pada bangsa Israel dalam sebuah keluarga inti. Korelasi Kejadian 1:27-28; 2:21-25 dengan Ulangan 6:1-25 adalah bahwa Musa memperhatikan kemantapan hubungan dalam keluarga dengan pendidikan yang mendalam. Dengan lain kata, Musa

${ }^{8}$ Ade Kartini and Asep Maulana, "Model Pendidikan Karakter Dalam Keluarga," An-Nisa' : Jurnal Kajian Perempuan dan Keislaman 13, no. 2 (2020): 231-253.

${ }^{9}$ Yusuf BS, Keluarga Bahagia (Malang: STT Tabernakel, 1986), 3. berhasil menangkap rencana dan maksud Allah tentang keluarga, terbukti Musa menuliskan hal-hal yang terpenting dalam tulisan kitab pentatukh. ${ }^{10}$

$$
\text { Untuk itu, Ulangan 6:1-25 }
$$
sangatlah cocok dan relevan untuk membahas prinsip-prinsip keluarga sebagai pusat pendidikan dalam posisi sebagai dasar kekuatan iman setiap keluarga yang membawa dampak pertumbuhan gereja. Karena secara induktif bisa dilihat bahwa Ulangan 6:125, menyoroti tentang pendidikan yang dilakukan oleh orang tua terhadap anak atau setiap anggota keluarga dalam konteks umat Israel. Karena itu, semua merupakan perintah Allah dan menjadi suatu ketetapan umat Israel (U1. 6:1) dan memiliki dasar-dasar atau nilai-nilai yang penting. ${ }^{11}$

\section{METODE PENELITIAN}

Untuk mendapatkan data-data yang akurat dan dapat dipertanggungjawabkan, dalam penelitian ini penulis menggunakan metode deskriptif literatur. Dalam penggalian teks akan di pakai metode induktif. ${ }^{12}$ Dengan

10 Robetson Niccol, The Expository's Bible (Rapinds: Baker Book House, 1982), 524.

${ }^{11}$ Riris Eka Setiani, "Pendidikan Anak Dalam Keluarga," YINYANG: Jurnal Studi Islam, Gender dan Anak 13, no. 1 (2018): 105-116.

${ }^{12}$ Sonny Eli Zaluchu, "Strategi Penelitian 
metode ini penulis mempelajari Ulangan 6:1-25 secara keseluruhan, selanjutnya baru menambah dari buku lain mengenai prinsip-prinsip pendidikan yaitu mempelajari prinsip-prinsip keluarga Kristen sebagai pusat pendidikan menurut Ulangan 6:1-25 yang merupakan pewahyuan khusus ${ }^{13}$ dari sudut pandang kebenaran Firman Tuhan, sebab Alkitab adalah standar kehidupan orang percaya. Penulis menggali kebenaran-kebenaran secara studi teologis.

\section{PEMBAHASAN}

\section{Prinsip-Prinsip Keluarga Kristen Sebagai Pusat Pendidikan Menurut Ulangan 6:1-25}

Keluarga Sebagai Pusat Pengajaran

Pemahaman tentang keluarga sebagai pusat pendidikan ini tidak lepas dari maksud dan kebenaran Alkitab, yang diangkat dari kitab Ulangan 6:1-25. Musa menjelaskan tentang pola kehidupan keluarga yang direncanakan Allah bagi Israel di tanah Kanaan. Sebab keluarga merupakan tempat yang efektif dalam

Kualitatif Dan Kuantitatif Di Dalam Penelitian Agama," Evangelikal: Jurnal Teologi Injili dan Pembinaan Warga Jemaat 4, no. 1 (2020): 28.

13 Warisman Harefa, "Keunikan

Kekristenan Berakar Di Dalam Kesatuannya Dengan Kristus," Kurios 2, no. 1 (2018): 32.

14 Rafles Rudi Laua, "Pola Pembinaan sebuah pembinaan rohani. ${ }^{14}$ Menurut terjemahan King James, Musa pada dasarnya berjanji atas kehendak dan perintah Allah bahwa rumah tangga mereka masing-masing akan seperti berada di surga yang dinikmati di dunia ini, (heaven on earth, Ul. 11:21, KJV). ${ }^{15}$ Diberkati secara luar biasa secara jasmani dan rohani, karena ketaatan akan perintah Tuhan. Dalam Kitab Ulangan, Nabi Musa melukiskan dengan begitu indah serta menggambarkannya sebagai suatu kepuasan dan suasana damai yang tiada kunjung berakhir.

Dapat dipahami betapa indahnya kehidupan rumah tangga yang pada mulanya direncanakan Allah bagi umatNya itu. ${ }^{16}$ Kira-kira 1200 tahun kemudian, dengan perantaraan Nabi Maleakhi, Allah periksa kembali perilaku bani Israel semenjak bangsa Israel mendiami negeri perjanjian itu. Sebab keluarga bangsa Israel gagal memenuhi persyaratan Allah, sehingga tidak pernah menikmati kualitas kehidupan yang tinggi, yang semula Allah rancangkan bagi mereka (Kej. 1:27-28; U1. 6:1-25). Ketika membuat penilaian, Allah menunjukkan kepada Israel dalam

Berdasarkan Efesus 5: 22- 33 Bagi Pernikahan Dini Warga Jemaat Masa Kini," Missio Ecclesiae, no. Vol. 7 No. 2 (2018): Oktober (2018): 229-258.

${ }^{15}$ Derek Prince, Pernikahan Ikatan Yang Kudus (Jakarta: Yayasan Pekabaran Injil Immanuel, 1992), 20.

${ }^{16}$ Prince, Pernikahan Ikatan Yang Kudus. 
hal-hal mana yang telah gagal. Salah satu kegagalan mereka adalah kehidupan rumah tangga, yaitu dalam kehidupan rumah tangga bangsa Israel. $^{17}$ Ini merupakan kemerosotan beberapa keluarga dari bangsa Israel yang telah melalaikan keluarga sebagai pusat pendidikan. Perkataan Allah nyata dalam firman-Nya di kitab Maleakhi 2:13-14. Sesungguhnya mereka "menutupi mezbah Tuhan dengan air mata.

Hal yang sama sering terjadi juga masa sekarang, yaitu terlalu menonjolkan kehidupan yang sifatnya kelihatan (kekayaan, pekerjaan, kedudukan) dan tidak memperhatikan kehidupan keluarga sebagai pusat pendidikan. Dapat dinyatakan saat ini banyak orang sibuk melakukan kegiatan keagamaan, pekerjaan duniawi, tetapi pada kenyataannya kehidupan keluarga mereka mengalami kegagalan. ${ }^{18}$ Jadi, keagamaan belum tentu menjamin berhasil kehidupan rumah tangga. Bahkan sebaliknya, sering kali kesibukan yang berlebihan dengan urusan agama di luar rumah tangga, baik dari pihak suami atau istrinya, sehingga menjadi pangkal penyebab kegagalan sebuah keluarga.

17 Ibid.

18 Jay E. Adams, "Masalah-Masalah Dalam Rumah Tangga Kristen," 8th ed. (Jakarta: BPK Gunung Mulia, 2012).

${ }^{19}$ Prince, Pernikahan Ikatan Yang Kudus.
Historis mencatat bangsa Israel begitu merosot akhlaknya, sehingga mereka berani dan merasa berhak menetapkan standar sendiri mengenai pernikahan. Oleh sebab itu, Tuhan, memberikan peringatan kepada umat Israel, tentang pernikahan sebagai suatu segi yang penting, seperti perkawinan nabi Hosea. Menurut rencana-Nya yang kekal, "Pernikahan merupakan suatu perjanjian yang sakral dan yang mengikat (suatu covenant, dalam istilah bahasa Inggrisnya)."19

Mengingat banyaknya kegagalan yang dialami keluarga di masa dahulu dan masa sekarang, maka penting untuk membahas secara khusus keluarga sebagai pusat pendidikan, dengan penuh keseriusan. Ditinjau dari kitab Ulangan 6:1-25, ada tujuan keluarga dijadikan sebagai pusat pendidikan, prinsip-prinsip keluarga sebagai pusat pendidikan, dan tanggapan untuk menjadikan keluarga sebagai pusat pendidikan, serta hasil yang dicapai sebab keluarga sebagai pusat pendidikan. Harapannya keluarga yang menjadi rancangan dan rencana Allah itu dapat terlaksana ideal dan sempurna di hadapan Allah, ${ }^{20}$ berdasarkan prinsip-

20 Anderias Mesak Morib, "Pentingnya Pelayanan Konseling Pranikah," LOGON ZOES: Jurnal Teologi, Sosial dan Budaya 3, no. 1 (2020): 63-84. 
prinsip keluarga menurut Ulangan 6:1-25.

Keluarga penting dilihat dasar yang menopangnya. Karena kekukuhan dan ambruknya suatu bangunan keluarga dilihat dari dasar yang menopangnya. Oleh sebab itu penting untuk ditinjau secara khusus makna dasar yang mendukung keluarga sebagai pusat pendidikan. Seperti komentar Mary Selter Ainawirth. Perkembangan yang paling penting dari ilmu kedokteran jiwa selama lebih dari seperempat abad yang baru lalu adalah peningkatan yang mantap dari bukti bahwa kualitas pemeliharaan orang tua yang diterima seorang anak dalam tahun-tahun pertama kehidupannya sangat penting bagi kesehatan mentalnya di masa yang akan datang. ${ }^{21}$ Memang beberapa ahli meramalkan keluarga di masa yang akan datang dapat dipecahkan lewat lembaga keluarga. Namun penyelidikan telah menyimpulkan bahwa tidak ada tempat seperti rumah bila orang sampai berbicara tentang memenuhi tuntutan kebutuhan anak-anak. Ini suatu masukan untuk menetapkan suatu dasar yang kokoh terhadap pendidikan dalam keluarga yang benar. Sebab sejatinya pendidikan agama dalam keluarga bukan hanya mengajarkan pengetahuan agama Kristen, tetapi

21 Jean Fleming, Hati Seorang Ibu (Bandung: Yayasan Kalam Hidup, 1982), 17.

${ }^{22}$ Yonatan Alex Arifianto, "Pentingnya Pendidikan Kristen Dalam Membangun keluarga juga dapat menanamkan keteladanan sehingga dapat saling menguatkan dan menopang. ${ }^{22}$

Para ahli dan peneliti menegaskan kebijaksanaan yang konvensial, anakanak diingini dan diterima. Mereka (anakanak) membutuhkan kesinambungan dalam hubungan mereka dengan orang tua mereka secara biologis maupun psikologis; mereka membutuhkan bimbingan untuk menanggulangi tuntutan masa pertumbuhan dan mereka perlu mengetahui bahwa ada kualitas yang tetap dan dapat diandalkan didunia ini. ${ }^{23}$ Kenyataan dasar keluarga sebagai pusat pendidikan yang ideal adalah pemahaman prinsip-prinsip kebenaran yang tertuang dalam kitab Ulangan 6:125.

\section{Pendidikan dalam Keluarga adalah Perintah Tuhan}

Bagian pertama sebagai konsep dasar keluarga dijadikan pusat pendidikan adalah berdasarkan perintah ketetapan Tuhan (Ul. 6:1. Konteks historisnya adalah dalam setiap keluarga Israel harus tetap dijalankan suatu konsep pendidikan berdasarkan sepuluh hukum Taurat yang

Kerohanian Keluarga Di Masa Pandemi Covid19," Regula Fidei Jurnal Pendidikan Agama Kristen 5, no. 2 (2020): 94-106. 
diterima Musa di Gunung Sinai (Ul. 5:133). Pengajaran itu tidak cukup dalam perjalanan di padang gurun saja, tetapi sampai menduduki negeri Kanaan (tanah perjanjian). Bentuk kata "perintah" ini menuntut suatu keharusan bagi setiap umat Israel untuk dijadikan dasar pendidikan dalam keluarga. ${ }^{24}$ Dalam kata סאוה bentuk noun menunjukkan pengertian perintah sebagai suatu subyek dari kalimat, yang penting untuk dituruti. Bentuk feminin memiliki arti, yaitu: "Pertama, indikasi seks; Kedua, imajinasi obyek; Ketiga, bagian tubuh; Keempat, nama kota, negara; Kelima, ide abstrak; Keenam, konsep netral; Ketujuh, kelompok; Kolektif."25 Makna kata סאוה mengacu pada bentuk feminin yang menyatakan arti suatu ide abstrak dalam bentuk ketegasan terhadap suatu perintah yang telah dinyatakan Allah, lewat Musa (konteks historis).

Jadi makna noun dan Feminin yang muncul dalam bentuk pelaksanaan tiap anggota keluarga mempunyai maksud perintah itu merupakan suatu obyek utama dalam Ulangan 6:1 sebagai suatu dasar

\footnotetext{
${ }^{24}$ Ronald J. Williams, Hebrew Syntax An Outline (London: University of Toronto Press, 1986), 37.

${ }^{25}$ Williams, Hebrew Syntax An Outline.

26 A.K.i Marheni, "Komunikasi Interpersonal Dalam Pernikahan," Counsecling and personal development 1, no. 1 (2019): 11.

${ }^{27}$ Kristina Herawati, "Pastoral Konseling Kristen Dalam Memurnikan Konsep Orang Tua
}

keluarga menjadi pusat pendidikan, yang menampakkan ide abstrak, tetapi penuh ketegasan. Namun semuanya ini menuntut tindakkan yang serius dengan penuh tanggung" jawab untuk mengutamakan keluarga melaksanakan segala perintah ketetapan Tuhan dalam hukum-hukum-Nya, sebagai pusat pendidikan (bdk. Ul. 4:9; 6:2-7) dengan komunikasi yang efektif. ${ }^{26}$

Sebab Tuhan merindukan agar seumur hidup keluarga orang-orang percaya bahkan sampai anak cucunya takut akan Tuhan dan berpegang kepada segala ketetapan dan perintah Tuhan. Bahkan keluarga atau setiap pernikahan menjadi tempat yang esensi ikatan kedua insan. $^{27}$ Mengingat keberadaan sekolah dan gereja tidak banyak memenuhi kebutuhan dasar anak namun dalam keluarga dapat memenuhi kebutuhankebutuhan tersebut terlebih kebutuhan akan keteladanan. ${ }^{28}$ Sebab sejatinya keluarga merupakan lingkungan yang terbaik dalam upaya membina kecerdasan spiritual anak. Dan hanya keluarga yang dapat memenuhi kebutuhan-kebutuhan

\footnotetext{
Yang Menikahkan Anak Laki-Laki Di Bawah Umur 17 Tahun," SCRIPTA: Jurnal Teologi dan Pelayanan Kontekstual 4, no. 2 (2020): 131-143.

${ }^{28}$ Yakub Hendrawan Perangin Angin, Tri Astuti Yeniretnowati, and Yonatan Alex Arifianto, "Peran Keluarga Kristen Untuk Bertahan Dan Bertumbuh Dalam Menghadapi Tantangan Di Era Disrupsi Dan Pandemi Covid-19," JURNAL TEOLOGI RAHMAT 6, no. 2 (2020): 128-141.
} 
terdalam akan; Pertama, kasih sayang; Kedua, disiplin; Ketiga, penghargaan; Keempat, pertumbuhan; Kelima, keamanan rohani. Kelima hal tersebut adalah merupakan lima tanggung jawab orang tua. ${ }^{29}$ Perintah untuk mengajar anak-anak atau setiap anggota keluarga yang ada itu dipertegas dalam Mazmur 78:5-8. Bila ditengok kembali ke bahasa aslinya dalam makna "sawa" atau perintah, ada beberapa macam arti yang memperkuat konsep perintah keluarga sebagai pusat pengajaran. Pertama, perintah digunakan untuk keputusan dari seorang anak-Nya (1 Sam. 17:20), seorang petani kepada pekerjaannya (Rut. 2:9), seorang raja kepada pelayan-pelayannya (2Sam. 21:14). Refleksinya adalah tanggapan manusia untuk memenuhi kebenaran perintah Tuhan (2Sam. 7:7; 1Raj. 1:35). Kedua, "Perintah Tuhan "adalah kata yang berarti eksistensi atau kehidupan (Mzm. 33:9). Ketiga, apa yang Tuhan perintahkan untuk dilakukan, untuk memperlengkapi. Keempat, Tuhan menjamin kebenaran dengan perintahNya. Perintah-Nya dengan perjanjian (Mzm. 105:8; 111:9) dan akan memberkati dengan melimpah di tanah

\footnotetext{
29 Wanda Humble, Diktat Psikologi (Yogyakarta: STT Injili Indonesia, 1996), 6.

${ }^{30}$ Laird Harris, Theological Wordbook of The Old Testament, Vol. 2 (Chicago: Moody Press, 1981), 757.

Nicolas Kandowangko Leis
}

perjanjian (Ul. 28:8; Mzm. 133:3). 5. Disertai dengan berkat apabila menaati perintah Tuhan (U1. 11; 26). ."30

Dengan melihat penggunaan dari kata "sawa" dalam bahasa asli, maka terdapat ada janji berkat yang akan dinyatakan Allah kepada setiap keluarga, jika memenuhi syarat dengan menjadikan ketetapan atau perintah Tuhan sebagai dasar keluarga menjadi pusat pendidikan sesi pertama. ${ }^{31}$

Studi historis berdasarkan perintah literal yang ditujukan bagi bangsa Israel, ketika Musa memimpin bangsa ini keluar dari tanah Mesir selama 40 tahun yang berpusat Kepada hubungan bangsa Israel dengan Tuhan yang membawa kepada pembinaan terutama pada pusat, Pertama, penyembahan; Kedua Kerajaan Allah.“ Kata "perintah" secara literal dipusatkan kepada penyembahan dan kerajaan Allah. Bahwa Allah senang melihat sebuah keluarga yang melayani Dia dengan setia dari generasi ke generasi. Ia menggunakan kaum Rekhab sebagai contoh dari generasi yang menaati bapa leluhurnya dan membandingkan dengan ketidaktaatan Israel kepada Bapa Surgawi (lih. Yer. $35: 16 ; 13)$. Kutipan ini dijelaskan dalam

Yigibalom Nelly J. Waani, "Peranan Interaksi Anggota Keluarga Dalam Upaya Mempertahankan Harmonisasi Kehidupan Keluarga Di Desa Kumuluk Kecamatan Tion Kabupatem Lanny Jaya," Journal Volume II. No. 4. Tahun 2013 II, no. 4 (2013): 19. 
karangan Jein Fleming, menyatakan: Ketaatan hukum Rekhab dari generasi ke generasi menyenangkan hati Allah. Ia memberkati mereka karena kesetiaan mereka yang tak tergoyahkan terhadap perintah-perintah nenek moyangnya. ${ }^{32}$ Keluarga Rekhab bukan hanya berpihak kepada Tuhan yang memberikan perintah saja, tetapi juga bertekad dan ada motivasi dalam menjalankan keluarga sebagai pusat pendidikan. Sehingga yang terpenting dalam kehidupan keluarga adalah menempatkan perintah dan ketetapan Allah. Sebagai dasar dalam keluarga untuk mendidik setiap anggota keluarga dengan benar. ${ }^{33}$ Pasti jika mau hidup dalam perintah Allah yang bersifat subjek dan berbentuk ketegasan ini, maka ada suatu berkat-berkat Ilahi yang menunggu, dengan tercerminnya suatu kehidupan rumah tangga yang bahagia dan harmonis, sesuai rencana Allah (Kej. 1:2728).

\section{Pendidikan dalam Keluarga adalah} Perjanjian dengan Allah

Bagian kedua sebagai penopang keluarga menjadi pusat pengajaran adalah suatu perjanjian atau hubungan yang erat

\footnotetext{
${ }^{32}$ Herbert Locyker, Ellicots Comentary on The Whole Bible Deuteronomy (Michigan: Grand Rapids, 1981), 25.

${ }^{33}$ Federans Randa, "Karya Keselamatan Allah Dalam Yesus Kristus Sebagai Jaminan
}

dengan segala ketetapan Allah. Jadi perjanjian yang dimunculkan dalam ungkapan ayat 3, "seperti yang telah difirmankan Tuhan, Allah nenek moyangmu." Ada suatu hubungan timbal balik dalam kehidupan keluarga. Makna gramatika kata "perjanjian" dari Ulangan 6:3 dari kata Ibrani diber. Mempunyai bentuk dasar dabar, berarti firman. Sehingga lebih tepat penggunaan dalam Ulangan 6:3 adalah makna ungkapan "seperti yang telah difirmankan Tuhan, Allah nenek moyangmu. Ungkapan kata "perjanjian" dalam Ulangan 6:3 ini memberikan ketegasan adanya suatu hubungan yang erat antara bentuk perjanjian dan Firman Tuhan itu. Jika diparshing makna kata "mengandung" bentuk: Piel, Perfeck, 3 Maskulin, Tunggal. Bentuk Piel mengandung arti: 1. Intensif; 2. Factitive; 3. Causatif (sebab akibat); 4. Pluratif atau Repetitive; 5. Denominatif; 6. Decolative; 7. Pritative. Namun bentuk Piel yang muncul dalam kata diber mengacu kepada bentuk intensif yang berarti memperkuat atau mempertegas ungkapan seperti yang telah dijanjikan atau difirmankan TUHAN, Allahmu.” Bentuk perfek artinya:

Manusia Bebas Dari Hukuman Kekal Allah," LOGON ZOES: Jurnal Teologi, Sosial dan Budaya 3 , no. 1 (2020): 35-62, https://ejournal.stteriksontritt.ac.id/index.php/logon/article /view/17. 
Pertama, tindakkan yang komplit ditujukan dengan perilaku nyata dalam pikiran dan perbuatan; Kedua, pengalaman; Ketiga, kondisi; Keempat, stative." Makna yang terkandung dalam kata diber bentuk perfek menunjukkan kepada suatu tindakkan yang kompleks disertai perbuatan dan pikiran yang menyeluruh. Ini mengacu kepada suatu perjanjian dalam bentuk dipertegas kembali untuk dapat melakukan Firman itu dengan suatu tindakan atau pemikiran yang komplit dan mendalam.

Lebih lanjut kata "dabar" menurut Laird Harris mempunyai beberapa pengertian kekuatan makna dalam Ulangan 6:3. Pertama, dabar. Kata berbicara, perkataan, sesuatu, tidak ada sesuatu, segala sesuatu, tidak ada (dengan negatif), perintah, hal, perbuatan, kejadian, atau peristiwa, sejarah. Kedua, “Sepuluh perintah" (Kel. 34:28; U1. 4:13; 10:4), 10 perintah (debarim). Kata "dabar" kadang diterjemahkan memberitakan apa yang dikerjakan. ${ }^{34} \mathrm{Hal}$ ini dilatarbelakangi ketika Allah mengikat perjanjian dengan Musa untuk memberikan tanah Kanaan, yang ditegaskan dalam sebuah perjanjian Allah dengan umat-Nya, yaitu: "Kamu telah

\footnotetext{
${ }^{34}$ Harris, Theological Wordbook of The Old Testament, Vol. 2.

${ }^{35}$ Locyker, Ellicots Comentary on The
}

menjadikan kekuasaan di tanah perjanjian, keadaan Israel di tanah perjanjian itu merupakan kelanjutan mereka, kemerdekaan seluruhnya dalam menyelesaikan maksud yang membawa mereka menjalankan hukum Tuhan."35

Ketetapan yang diberikan Allah kepada bangsa Israel untuk berkuasa atas tanah perjanjian itu memiliki kemerdekaan sepenuhnya. Yaitu mengenai perjanjian atau Firman yang telah disampaikan bagi hamba-Nya untuk menjalankan hukum Tuhan. Bahkan Allah mempertegas kembali kepada bangsa Israel mengenai panggilan kepada keluarga Saja untuk menaati Tuhan, dan juga kepada bangsa secara keseluruhan, sebagaimana ditegaskan dalam pernyataan berikut: TUHAN, Allah kami adalah TUHAN yang satu. Bentuk kata ini dikenal dengan sebutan SHEMA (dengarlah) yang berasal dari bahasa Ibrani. Dan dipergunakan dalam pelayanan Yahudi dan termasuk bahasa sehari-hari. Pernyataan mereka adalah dalam keaslian tunggal yang pendek dan termasuk kepercayaan Yahudi yang bersifat paksaan: "Allah TUHAN kami, Allah yang satu. “ ${ }^{36}$ Perintah dan ketetapan Allah dalam hubungan suatu perjanjian ini

\footnotetext{
Whole Bible Deuteronomy.

${ }^{36}$ Cook, The Bible Comentary (Michigan: Grand Rapids, 1981), 824.
} 
penting untuk didengarkan. Hal ini merupakan tema dan tujuan Musa dalam kitab Ulangan (U1. 6:4). ${ }^{37}$ Dipertegas oleh Andrew E. Hill dan John H. Walton. Pesan dalam kitab ini adalah pesan hukum dan pesan perjanjian. Sudah lama pesan ini disampaikan oleh orang-orang Yahudi dengan Shema yang terkenal itu ("Dengarlah" kata Ibrani pertama pada bagian ini) terdapat dalam pasal 6:4-9, tetapi diringkaskan dalam pasal 10:12$13 .^{38}$

Makna kata "Dengarlah" ini merupakan suatu ajakan yang bersifat tegas. Pernyataan Allah kepada bangsa Israel melalui hamba-Nya, supaya bangsa Israel taat kepada perintah dan tetap hidup dalam ketetapan, seperti yang telah difirmankan-Nya. Perjanjian yang diungkapkan ini suatu pengalaman antara Tuhan dengan bangsa Israel. Dia akan membuat mereka menjadi keturunan bangsa yang mulia. 17:6; Janji ini komplit dalam pembahasan Kejadian 12:1; 18:18. Dapat disimpulkan bahwa perjanjian yang muncul ini, merupakan suatu peringatan kembali.
Pendidikan dalam Keluarga Bersumber Pada Kuasa Mukjizat Allah

Dasar keluarga sebagai pusat pendidikan yang ketiga adalah bersumber pada kuasa mukjizat Allah. Diungkapkan dalam Ulangan 6:20-23, dengan kuasakuasa ajaib yang dinyatakan Allah sepanjang perjalanan umat Israel di padang gurun dan saat kelepasan umat Israel dari Mesir. Makna gramatikal dalam Ulangan 6:20-23 dari kata kuasa dan mukjizat yaitu "kuasa" dari kata Ibrani "umopetim" (bhs. Inggris. Signs) dan kata "mukjizat" dari kata Ibrani "umopetim", menunjukkan Noun, Maskulin, Jamak. Bentuk Noun berarti: "1. Subyek kalimat; 2. Obyek kalimat; 3. Milik: 4. Hubungan kata kerja dengan umopetim; 5. Maksud dengan "umopetim " ; 6. Hasil dengan "umopetim " Namun untuk kata mukjizat atau kuasa dalam bagian Ulangan 6:20-23 ini lebih menunjukkan kepada obyek kata kerja di mana Allah membuat suatu tandatanda dan mukjizat-mukjizat yang dahsyat. Bentuk maskulin berarti: Pertama, indikasi sex kejantanan; Kedua, gramatikal untuk pengertian obyek; Ketiga, di dalam jamak merupakan ekspresi ide abstrak."39 Namun kata "umopetim "dalam bentuk maskulin

Survei Perjanjian Lama, Cetakan Pe. (Malang: Penerbit Gandum Mas Malang, 1996).

${ }^{39}$ Williams, Hebrew Syntax An Outline.
Injili Indonesia, 1996), 112.

38 Andrew E Hill and John H. Walton, 
menunjukkan kepada suatu bentuk jamak yang mengandung suatu ekspresi atau tindakan, meskipun ide abstrak. Jadi makna kuasa atau mukjizat ini mengandung suatu pengertian noun dan maskulin yang menyatakan bahwa kuasa dan mukjizat itu merupakan obyek yang Allah lakukan sebagai suatu ide abstrak, tetapi dalam tindakkannya penuh ekspresi yang nyata.

Kuasa-kuasa atau mukjizatmukjizat dalam Ulangan 6:20-23 dilatarbelakangi ketika Allah melakukan mukjizat bagi Israel, ketika Allah menuntun bangsa Israel keluar dari tanah Mesir (perbudakan), sebagaimana dijelaskan oleh Cook. Allah telah membawa keluar dari Mesir. Singkatnya keterangan kewajiban dari hukum membawa beberapa macam dasar di atas pesan Allah untuk Israel dari Sinai (Kel. 19:3-6). Berpeganglah pada hukum Allah pada bangsa Israel di tanah perjanjian ketika Dia telah memberikan kemenangan pada kehidupan bangsa mereka. ${ }^{40}$ Pastilah dengan adanya mukjizat dan kuasa Allah, maka akan diceritakan dari keturunan ke keturunan, sebagai suatu peringatan. Sehingga kehidupan rumah tangga akan

\footnotetext{
${ }^{40}$ Loyker, Ellicott's Comentary on The Whole Bible Deuteronomy (Michigan: Grand Rapids, 1986), 26-27.

41 Kanti Widiastuti and Els Rampisela, "Implementasi Ajaran Tentang Pernikahan Berdasarkan I Korintus 7 Di Kalangan Gembala
}

senantiasa mengingat keberadaan Tuhan dan berserah kepada Tuhan dengan penyerahan diri secara total.

\section{Tujuan Keluarga Sebagai Pusat Pendidikan}

Mengingat keberadaan manusia atau keluarga merupakan gagasan Allah (Kej. 1:27-28, 31). Ia yang telah menentukan dan mempersatukan laki-laki dan perempuan yang pertama dalam pernikahan. ${ }^{41}$ Pada mulanya hubungan mereka baik. Allah memberkati. Hubungan itu dimaksudkan untuk menimbulkan suasana kasih dan kepemimpinan untuk anak-anak yang merupakan buahnya. Semua akan didapat dengan menjadikan keluarga sebagai pusat pendidikan. ${ }^{42}$ Maka Roy Lessin berkomentar tentang keberadaan keluarga: Tujuan Allah bagi keluarga Kristen pada mulanya baik: yaitu sebagai pusat pendidikan. Namun karena adanya keluarga pertama, yaitu: Adam dan Hawa memilih untuk memisahkan diri dari Allah, keluarga mengalami kegagalan dalam mencapai tujuan keluarga sebagai pusat pendidikan. Kegagalan keluarga yang pertama disebabkan karena mereka

Sidang Gereja Pantekosta Di Indonesia, Kabupaten Jember," Jurnal Teologi Gracia Deo 2, no. 2 (2020): 80-93.

42 Ruwi Hastuti, "Pendidikan Agama Kristen Dalam Keluarga Sebagai Pusat Bermisi," Jurnal Antusias 2, no. 4 (2013): 23-68. 
memutuskan untuk bertindak sesuka mereka sendiri. Mereka menolak kekuasaan Allah atas hidup mereka dan atas kehidupan keluarga. Maka timbul persoalan-persoalan, tetapi Allah tidak pernah menghendaki keluarga berfungsi tanpa Dia. ${ }^{43}$

Keluarga-keluarga masa sekarang kelihatannya banyak mengulangi kesalahan-kesalahan keluarga yang pertama itu. Harus dimengerti sekali lagi, bukan lembaga keluarga itu yang salah, namun cara hidup keluarga itu yang salah. Oleh sebab itu penting untuk mengkaji dalam Ulangan 6:1-25 yang memfokuskan kepada tujuan bahwa keluarga sebagai pusat pendidikan. Mungkin diambil dari historis Israel, kemudian dimasukkan kepada dunia Kristen masa sekarang, sebagai suatu introspeksi diri bahwa keluarga tepat sebagai pusat pendidikan. Karena keluarga adalah tempat pendidikan yang pertama dan terutama. ${ }^{44}$ Adapun tujuan-tujuan untuk menjadikan keluarga sebagai pusat pendidikan adalah: Pertama, seumur hidup takut akan Tuhan dan berpegang kepada segala firman Tuhan; ${ }^{45}$ Kedua, baik keadaan jasmani dan rohani; Ketiga, mendapatkan

${ }^{43}$ Lessin, Disiplin Keluarga.

${ }^{44}$ Reni Triposa, Yonatan Alex Arifianto, and Yudi Hendrilia, "Peran Guru PAK Sebagai Teladan Dalam Meningkatkan Kerohanian Dan Karakter Peserta Didik," Jurnal Pendidikan keturunan yang indah dan hidupnya berkenan di hadapan Tuhan.

\section{KESIMPULAN}

Uraian mengenai "Prinsip-Prinsip Keluarga Sebagai Pusat Pendidikan Berdasarkan Ulangan 6:1-25" ini sangatlah indah. Memiliki tujuan membangkitkan, mendorong dan membangun kembali bangkitnya kehidupan dan keutuhan keluarga sebagai pusat pendidikan dengan makna dasar "Shema" suatu perintah dengarlah." Konsep ini memberikan inspirasi bahwa keberadaan keluarga sangatlah diperhatikan secara khusus oleh Tuhan. Perintah khusus tentang kehidupan keluarga bangsa Israel dapat ditransferkan dalam prinsip-prinsip kehidupan keluarga masa kini, berdasarkan prinsip-prinsip dalam Ulangan 6:1-25. Keluarga memang sangat indah sekali. Tetapi berbagai dekade banyak perbedaan dari segi budaya dan adat latar belakang kehidupan keluarga. Misalnya tradisi keluarga dunia kuno (Yahudi, Yunani, Romawi) hampir memiliki ciri yang sama tentang keberadaan wanita yang terbelakang dan tidak terhormat dibanding laki-laki. tetapi

\footnotetext{
Agama Kristen (JUPAK) 2, no. 1 (2021): 109-126. 45 Peniel C.D. Maiaweng, "Perceraian Dan Pernikahan Kembali," Jurnal Jaffray 15, no. 1 (2017): 97.
} 
perbedaan yang mencolok adalah pendidikan pada masa Yahudi berdasarkan agama Hukum Taurat, Yunani berdasarkan filsafat dan Romawi berdasarkan kemiliteran. Ada berbagai macam kebudayaan yang dijadikan dasar untuk mendidik keluarga.

Ulangan 6:1-25 sangat tepat memberikan suatu jawaban untuk memulihkan keluarga yang kebanyakan hancur, khususnya di kalangan orang percaya. Dasar membina keluarga yang harmonis, sebagai pusat pendidikan, yaitu: Pertama, perintah dan ketetapan Tuhan; Kedua, perjanjian Allah dengan hambaNya; Ketiga, kuasa mukjizat Allah. Untuk menjadikan keluarga sebagai pusat pendidikan, ada suatu tujuan-tujuan tertentu. Adapun tujuan-tujuan untuk menjadikan keluarga sebagal pusat pendidikan adalah: Pertama, seumur hidup takut akan Tuhan dan berpegang kepada segala firman Tuhan; Kedua, baik keadaan jasmani dan rohani; Ketiga, mendapatkan keturunan yang indah dan hidupnya berkenan di hadapan Tuhan.

\section{DAFTAR PUSTAKA}

Adams, Jay E. "Masalah-Masalah Dalam Rumah Tangga Kristen." 8th ed. Jakarta: BPK Gunung Mulia, 2012.

Angin, Yakub Hendrawan Perangin, Tri Astuti Yeniretnowati, and Yonatan
Alex Arifianto. "Peran Keluarga

Kristen Untuk Bertahan Dan

Bertumbuh Dalam Menghadapi

Tantangan Di Era Disrupsi Dan

Pandemi Covid-19." JURNAL

TEOLOGI RAHMAT 6, no. 2 (2020).

Arifianto, Yonatan Alex. "Pentingnya

Pendidikan Kristen Dalam

Membangun Kerohanian Keluarga

Di Masa Pandemi Covid-19."

Regula Fidei Jurnal Pendidikan

Agama Kristen 5, no. 2 (2020).

Bariyah, Siti Khusnul. "Peran Tripusat

Pendidikan Dalam Membentuk

Kepribadian Anak." Jurnal

Kependidikan 7, no. 2 (2019).

BS, Yusuf. Keluarga Bahagia. Malang:

STT Tabernakel, 1986.

Krisis Keluarga. Malang: STT

Tabernakel, 1986.

Cook. The Bible Comentary. Michigan: Grand Rapids, 1981.

Fleming, Jean. Hati Seorang Ibu.

Bandung: Yayasan Kalam Hidup, 1982.

GUNAWAN, AGUNG. "Hamba Tuhan Dan Keluarga." SOLA GRATIA: Jurnal Teologi Biblika dan Praktika 3, no. 1 (2020).

Harefa, Warisman. "Keunikan Kekristenan Berakar Di Dalam Kesatuannya Dengan Kristus.” Kurios 2, no. 1 (2018).

Harmadi, Mariani, and Agung Jatmiko. "Pembelajaran Efektif Pendidikan Agama Kristen Generasi Milenial." PASCA : Jurnal Teologi dan Pendidikan Agama Kristen 16, no. 1 (2020).

Harris, Laird. Theological Wordbook of The Old Testament, Vol. 2. Chicago: Moody Press, 1981. 
Hastuti, Ruwi. "Pendidikan Agama Kristen Dalam Keluarga Sebagai Pusat Bermisi." Jurnal Antusias 2, no. 4 (2013).

Hill, Andrew E, and John H. Walton. Survei Perjanjian Lama. Cetakan Pe. Malang: Penerbit Gandum Mas Malang, 1996.

Humble, Wanda. Diktat Psikologi. Yogyakarta: STT Injili Indonesia, 1996.

Irawati, Enny. "Kekudusan Hidup Menurut 1Tesalonika 4:1-8 Relevansinya Terhadap Pemahaman Pemuda Di Gkai Sunter." Jurnal Teologi Biblika 5, no. 1 (2020).

Jatmiko, Yudi. "'Sampai Maut Memisahkan Kita?': Pandangan Mengenai Pernikahan, Perceraian, Dan Pernikahan Kembali Berdasarkan Perspektif Iman Kristen." SOLA GRATIA: Jurnal Teologi Biblika dan Praktika 1, no. 2 (2021).

Kartini, Ade, and Asep Maulana. "Model Pendidikan Karakter Dalam Keluarga." An-Nisa' : Jurnal Kajian Perempuan dan Keislaman 13, no. 2 (2020).

Kristina Herawati. "Pastoral Konseling Kristen Dalam Memurnikan Konsep Orang Tua Yang Menikahkan Anak Laki-Laki Di Bawah Umur 17 Tahun." SCRIPTA: Jurnal Teologi dan Pelayanan Kontekstual 4, no. 2 (2020).

Laua, Rafles Rudi. "Pola Pembinaan Berdasarkan Efesus 5 : 22- 33 Bagi Pernikahan Dini Warga Jemaat Masa Kini." Missio Ecclesiae, no. Vol. 7 No. 2 (2018): Oktober (2018).
Leis Yigibalom Nelly J. Waani, Nicolas Kandowangko. "Peranan Interaksi Anggota Keluarga Dalam Upaya Mempertahankan Harmonisasi Kehidupan Keluarga Di Desa Kumuluk Kecamatan Tion Kabupatem Lanny Jaya." Journal Volume II. No. 4. Tahun 2013 II, no. 4 (2013).

Lessin, Roy. Disiplin Keluarga. Malang: Gandum Mas, 1987.

Locyker, Herbert. Ellicots Comentary on The Whole Bible Deuteronomy. Michigan: Grand Rapids, 1981.

Loyker. Ellicott's Comentary on The Whole Bible Deuteronomy. Michigan: Grand Rapids, 1986.

Maiaweng, Peniel C.D. "Perceraian Dan Pernikahan Kembali." Jurnal Jaffray 15, no. 1 (2017): 97.

Marheni, A.K.i. "Komunikasi Interpersonal Dalam Pernikahan." Counsecling and personal development 1, no. 1 (2019).

Mauboy, Anita, and Sjanette Eveline. "Pemahaman Pernikahan Kudus Suku Dawan Ditinjau Dari Kejadian 1:27-28." Journal KERUSSO 4, no. 2 (2019).

Morib, Anderias Mesak. "Pentingnya Pelayanan Konseling Pranikah." LOGON ZOES: Jurnal Teologi, Sosial dan Budaya 3, no. 1 (2020).

Niccol, Robetson. The Expository's Bible. Rapinds: Baker Book House, 1982.

Owens, John Joseph. Analitycal Key to The Old Testement, Vol. 1. Michigan: Grand Rapids, 1989.

Prince, Derek. Pernikahan Ikatan Yang Kudus. Jakarta: Yayasan Pekabaran Injil Immanuel, 1992. 
Randa, Federans. "Karya Keselamatan Allah Dalam Yesus Kristus Sebagai Jaminan Manusia Bebas Dari Hukuman Kekal Allah." LOGON ZOES: Jurnal Teologi, Sosial dan Budaya 3, no. 1 (2020).

Reed, Carl. Torah. Yogyakarta: STT Injili Indonesia, 1996.

Scheuneman, D. Romatika Kehidupan Suami Istri. Malang: Gandum Mas, 1992.

Setiani, Riris Eka. "Pendidikan Anak Dalam Keluarga." YINYANG: Jurnal Studi Islam, Gender dan Anak 13, no. 1 (2018).

Sibarani, Yosua, and Yonatan Alex Arifianto. "Studi Analisis Makna Kata 'Berahi' Dan 'Berkuasa' Dalam Kejadian 3:16 Dan Implikasinya Bagi Rumah Tangga Kristen Masa Kini." Sola Scriptura: Jurnal Teologi 1, no. 2 (2020).

Stevanus, Kalis. "Sikap Etis Gereja Terhadap Perceraian Dan Pernikahan Kembali." Jurnal Kurios Volume 4, no. 2 (2018).

Triposa, Reni, Yonatan Alex Arifianto, and Yudi Hendrilia. "Peran Guru PAK Sebagai Teladan Dalam Meningkatkan Kerohanian Dan Karakter Peserta Didik." Jurnal Pendidikan Agama Kristen (JUPAK) 2, no. 1 (2021).

Umrati, and Hengki Wijaya. Analisis Data Kualitatif Teori Konsep Dalam Penelitian Pendidikan. Sulawesi Selatan: Sekolah Tinggi Theologia Jaffray, 2020.

Widiastuti, Kanti, and Els Rampisela. "Implementasi Ajaran Tentang Pernikahan Berdasarkan I Korintus 7 Di Kalangan Gembala Sidang
Gereja Pantekosta Di Indonesia, Kabupaten Jember." Jurnal Teologi Gracia Deo 2, no. 2 (2020).

Williams, Ronald J. Hebrew Syntax An Outline. London: University of Toronto Press, 1986.

Zaluchu, Sonny Eli. "Strategi Penelitian Kualitatif Dan Kuantitatif Di Dalam Penelitian Agama." Evangelikal: Jurnal Teologi Injili dan Pembinaan Warga Jemaat 4, no. 1 (2020). 
18 | SANCTUM DOMINE: Jurnal Teologi, vol. 11, no. 1 (2021) 